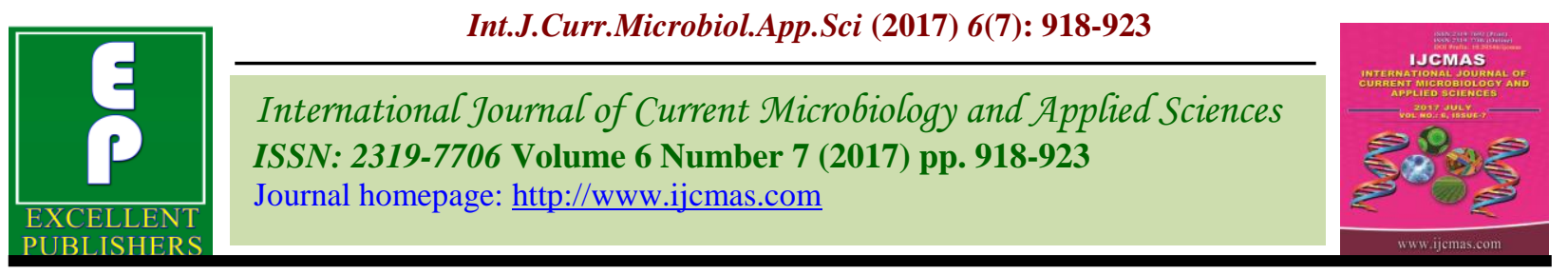

Original Research Article

https://doi.org/10.20546/ijcmas.2017.607.113

\title{
Assessment of Production Potential of Finger Millet (Eleusine coracana (L.) Gaertn.) under Rice-Fallow Conditions of North Coastal Zone of Andhra Pradesh, India
}

\author{
U. Triveni*, Y. Sandhya Rani, T.S.S.K. Patro, N. Anuradha and M. Divya \\ Acharya N.G. Ranga Agricultural University, Agricultural Research Station, \\ Vizianagaram, 535 001, A.P., India \\ *Corresponding author
}

\author{
A B S T R A C T
}

\section{Keywords \\ Finger millet, Rice Fallow conditions, Grain yield, Net Monetary Returns, B: C. \\ Article Info \\ Accepted: 14 June 2017 Available Online: 10 July 2017}

A field experiment was conducted during rabi, 2015-16 and 2016-17 in the farmers field at Gajularega village of Vizianagaram district to know the production potential of finger millet under rice fallow conditions. First year finger millet seed was broadcasted in standing crop of paddy and left the crop without undergoing thinning and gap filling or any intercultural operations. Second year, thinning and gap filling, intercultivation with hand weeding was done within thirty days after sowing. During both the years, eight finger millet varieties of different duration were tested for their suitability for cultivation in Rice fallow conditions. Experiment was laid out in randomized block design with three replications. Experimental results revealed that, significant improvement in the yield attributing characters and grain yield were observed in the second year compared to the first year, which indicates the effectiveness of thinning and gap filling, intercultivation with hand weeding operations. About 3-6 times improvement in net monetary returns was noticed in different treatments in the second year compared to previous year. Considering different varieties, performance of VR-900 is good, however it was on par with VR-762 (Bharathi), VR-847(Srichaitanya), Vakula and PRS-2. Further highest net monetary returns and B:C ratio were also observed with VR-900 followed by VR-762 and VR847.Lowest grain yields were recorded in the Udaramalligae during both years of study.

\section{Introduction}

In India, 11.65million ha of Rainfed Rice fallow areas are located in the states of Andhra Pradesh, Assam, Bihar, Chhattisgarh, Jharkhand, Karnataka, Madhya Pradesh, Orissa and West Bengal (Singh et al., 2012). These rice fallow lands offer a huge potential niche for growing second crop during winter. Planting a second rainfed crop after rainfed rice depends on availability of residual moisture in the soil and provisions of supplementary tube well irrigation.
The residual moisture left in the soil at the time of rice harvest is often sufficient to raise the short-duration crops. Food security to ever increasing population in India can be ensured by converting these vast areas of rice fallows into productive areas. In the North Coastal Zone of Andhra Pradesh, broadcasting of pulses like Black gram or Green gram one week before the harvest of rice crop is a common practice. Farmers used to get the bumper harvest of the second crop without 
going for any crop management practices like intercultivation, fertilization, crop protection etc. But, in recent times, pulses production in North Coastal Zone has been declined drastically due to impact of climate change. Raising temperatures, unpredictable monsoons cause uncertainty in the sowing time of the second crop and also increase the risk of pests and disease problems like Yellow Vein Mosaic Virus disease, powdery mildew, Cercospora leaf spot, leaf curl and stem fly.

To overcome these problems, farmers in the north coastal zone of Andhra Pradesh have been started growing of Finger millet crop instead of pulse crops. Finger millet is known for drought tolerance and also can adapt to a wide range of soil and climatic conditions though it prefers fertile, well-drained sandy to sandy loam soils, with a $\mathrm{pH}$ ranging from 5 to 7. Finger millet is also known for its rich nutritional composition.

Traditionally finger millet area is mainly concentrated in the hilly patches of the North Coastal Zone of A.P. With the introduction of Finger millet under Rice fallow lands; there is an immense scope to extend its area and production in the state. Moreover in recent days, the position of Finger millet in the daily food basket is getting strengthened in the back drop of heath complications, malnutrition and food security. Hence, it is an urgent need to develop a complete agronomic package for Rice fallow finger millet. As a part of it, a field experiment was conducted to know the production potential of finger millet under rice fallow situation and also to select the best suitable variety of finger millet for cultivation in rice fallows.

\section{Materials and Methods}

A field experiment was conducted during rabi, 2015-16 and 2016-17 in the farmers field of Gajularega village of Vizianagaram district. Experiment consisted of eight treatments tested in Randomized Block Design with three replications. During first year of experiment i.e. 2015-16, no crop management practices were followed (like rice fallow pulses) except fertilizer application. But during 2016-17 crop management practices like thinning and gap filling and hand weeding with inter cultivation were followed ten days after harvest of the paddy crop in addition to fertilizer application. Eight treatments include finger millet varieties of different duration viz., $\mathrm{T}_{1}$ :Udaramalliga(60-65days), $\mathrm{T}_{2}$ :VR-708 (Champavathi) (80-85 days), $\mathrm{T}_{3}$ :Maruthi (8590 days), $\mathrm{T}_{4}:$ PRS-2 (85-90 days), $\mathrm{T}_{5}$ : Vakula (100-105 days), $\mathrm{T}_{6}: \mathrm{VR}-847$ (Sri chaitanya) (110-115 days), $\mathrm{T}_{7}$ :VR-762(Bharathi)(110115days), T 8 :VR-900(110-117 days).

The soil of experimental site is Sandy clay loam in texture with $\mathrm{pH}-8.03$, EC-0.21dS/m, Organic carbon- $0.52 \%$, available $\mathrm{N}_{2}-213 \mathrm{~kg} / \mathrm{ha}$ (low), available $\mathrm{P}_{2} \mathrm{O}_{5}-52 \mathrm{~kg} / \mathrm{ha}$ (high) and available $\mathrm{K}_{2} \mathrm{O}-284 \mathrm{~kg} / \mathrm{ha}$ (medium). The seeds were soaked for one day and then kept them in gunny bags for one day to make them sprout. The sprouted seeds were broadcasted in the standing crop of paddy 10days before harvest as per the treatments. Fertilizer recommendation of $60-40-30 \mathrm{~kg} / \mathrm{ha}$ was followed.

Phosphorus in the form of diammonium phosphate was applied in the stand crop of paddy just before harvesting. While, half the quantity of nitrogen in the form of urea and potash in the form of murate of potash were applied immediately after harvest of the paddy crop and remaining half was applied at 30 days after first application.

Data on growth and yield attributes were taken at the time of harvest. The data was then subjected to statistical analysis by using standard statistical procedures suggested by Rangaswamy (1995). 


\section{Results and Discussions}

Initial plant population was significantly high during 2015-16 compared to 2016-17 (Table 1). High seed rate used due to uncertainty of crop stand establishment in standing paddy crop has resulted in very high finger millet plant population per square meter. During first year, the plant stand established was left without thinning and gap filling same as like rice fallow pulses. But, during 2016-17 due to inclusion of thinning and gap filling operation optimum plant population per unit area was maintained. Plant density and distribution are believed to have a profound effect on grain yield. Wade et al.,(1988) observed that the population of plants per square meter (density) and arrangement of individual plants within a square meter determine nutrient use and grain yield of sunflower. Plant height of VR-900 was significantly high during 201516 where as in 2016-17 plant height was high in PRS-2. But, during both the years' plant height was significantly low in the variety Udaramalligae.

All the yield contributing characters were significantly varied with different varieties and also with the inclusion of thinning and gap filling and intercultivation with hand weeding. Number of productive tillers per hill was significantly high during 2016-17 compared to the 2015-16 (Table 1). Optimum plant population per unit area might be the reason for more number of productive tillers per hill. When the plant density exceeds an optimum level, competition among plants for light above ground and nutrients below ground becomes severe. Consequently plant growth slows down and the grain yield decreases. However, very low plant density may not enable attainment of the yield plateau (Getahun et al., 2016). Variety VR-900 was found to be recorded maximum number of productive tillers per plant during both the years, however it was on par with VR-762
(Bharathi) during 2015-16 and also with VR762 (Bharathi), VR-847 (Sri Chaitanya), Vakula and PRS-2 during 2016-17 (Table 1). Ear head length and number of fingers per ear during 2016-17 were significantly higher compared to 2015-16 (Table 2). Abundant availability of optimum growth resources to individual plants might have contributed to the more yield attributing characters. Elevated competition created for solar radiation, moisture and nutrients due to very high plant densities during first year might be the reason for low yield attributes and grain yield. Ear head length was more in VR-762 (Bharathi) and it was on par with VR-847(Sri Chaitanya), Vakula and PRS-2 during 201516.But during 2016-17 Ear head length was maximum in VR-900 and it was statistically similar with VR-762 (Bharathi), VR-847(Sri Chaitanya) and Vakula. Fingers per ear were maximum for VR-900 during both the years, however it was on par with all other varieties except Udaramalligae in 2015-16 and Udaramalligae, VR-708(Champavathi) and Maruthi during 2016-17.Harvest index was not significantly affected by different treatments during both the years. Test weight was significantly high for VR-762(Bharathi) and it was closely followed by VR-900 and Vakula during 2015-16. But during 2016-17, maximum test weight was recorded in VR900 , which was statistically on par with VR762 (Bharathi) and VR-847 (Srichaitanya) (Table 2).

Grain and straw yields were significantly influenced by crop management practices. Around 200-300 percent improvement in grain yield was noticed in 2016-17 compared to 2015-16 (Table 3). Small crop management changes like thinning and gap filling has considerably reduced the competition among the plants for growth resources and in turn resulted in increased yield attributing characters and grain yield. 
Table.1 Effect of treatments on growth and yield attributes in rice fallow conditions

\begin{tabular}{|l|c|c|c|c|c|c|}
\hline Treatments & \multicolumn{2}{|c|}{$\begin{array}{c}\text { Initial plant } \\
\text { population } \\
\text { plants/m }\end{array}$} & \multicolumn{2}{|c|}{ Plant ht(cm) } & \multicolumn{2}{l|}{ Productive tillers/hill } \\
\hline & $\begin{array}{c}2015- \\
16\end{array}$ & $2016-17$ & $2015-16$ & $\begin{array}{c}2016- \\
17\end{array}$ & $2015-16$ & $2016-17$ \\
\hline $\mathrm{T}_{1}:$ Udaramalligae(60-65 days) & 475.00 & 62.3 & 70.9 & 67.7 & 1.06 & 2.7 \\
\hline $\begin{array}{l}\mathrm{T}_{2}: \text { VR-708(Champavathi)(80-85 } \\
\text { days) }\end{array}$ & 515.00 & 62.0 & 77.5 & 79.5 & 1.30 & 3.7 \\
\hline $\mathrm{T}_{3}:$ Maruthi (85-90 days) & 375.00 & 63.7 & 75.0 & 78.6 & 1.20 & 3.2 \\
\hline $\mathrm{T}_{4}:$ PRS-2 (85-90 days) & 464.00 & 60.7 & 79.4 & 84.3 & 1.35 & 4.0 \\
\hline $\mathrm{T}_{5}:$ Vakula (100-105 days) & 499.00 & 63.7 & 72.1 & 73.4 & 1.34 & 4.0 \\
\hline $\begin{array}{l}\mathrm{T}_{6}: \text { VR-847 (Sri chaitanya)(110-115 } \\
\text { days) }\end{array}$ & 590.00 & 69.7 & 88.8 & 76.8 & 1.54 & 4.1 \\
\hline $\mathrm{T}_{7}:$ VR-762(Bharathi)(110-115days) & 750.00 & 68.0 & 89.3 & 66.8 & 1.98 & 4.7 \\
\hline $\mathrm{T}_{8}:$ VR-900(110-117 days) & 763.00 & 67.3 & 95.2 & 76.6 & 2.10 & 4.8 \\
\hline CD (0.05) & 132.67 & $\mathrm{NS}$ & 10.49 & 10.2 & 0.41 & 1.0 \\
\hline CV \% & 13.68 & 7.3 & 7.39 & 7.7 & 15.70 & 14.6 \\
\hline
\end{tabular}

Table.2 Yield attributing characters of different finger millet varieties under rice - fallow conditions

\begin{tabular}{|c|c|c|c|c|c|c|c|c|}
\hline \multirow[t]{2}{*}{ Treatments } & \multicolumn{2}{|c|}{$\begin{array}{l}\text { Ear head } \\
\text { length }(\mathrm{cm})\end{array}$} & \multicolumn{2}{|c|}{ No of fingers/ear } & \multicolumn{2}{|c|}{ Harvest index $(\%)$} & \multicolumn{2}{|c|}{$\begin{array}{l}\text { Test } \\
\text { weight }(\mathrm{g})\end{array}$} \\
\hline & $\begin{array}{l}2015 \\
-16\end{array}$ & $\begin{array}{l}2016 \\
-17\end{array}$ & $\begin{array}{l}2015- \\
16\end{array}$ & 2016-17 & $\begin{array}{l}2015- \\
16\end{array}$ & $\begin{array}{l}2016- \\
17\end{array}$ & $\begin{array}{l}2015 \\
-16\end{array}$ & $\begin{array}{l}2016- \\
17\end{array}$ \\
\hline $\begin{array}{l}\mathrm{T}_{1}: \text { Udaramalligae }(60-65 \\
\text { days) }\end{array}$ & 6.31 & 6.4 & 5.27 & 6.0 & 24.28 & 25.2 & 2.52 & 2.60 \\
\hline $\begin{array}{l}\mathrm{T}_{2}: \text { VR- } \\
708 \text { (Champavathi)(80-85 days) }\end{array}$ & 5.89 & 7.1 & 6.41 & 6.1 & 22.84 & 25.9 & 2.64 & 2.77 \\
\hline $\mathrm{T}_{3}:$ Maruthi (85-90 days) & 6.21 & 6.5 & 6.56 & 6.1 & 21.33 & 25.3 & 2.87 & 3.06 \\
\hline $\mathrm{T}_{4}:$ PRS-2 (85-90 days) & 6.48 & 7.0 & 6.57 & 7.0 & 22.97 & 25.5 & 3.08 & 3.25 \\
\hline $\mathrm{T}_{5}:$ Vakula (100-105 days) & 6.88 & 7.5 & 6.67 & 7.1 & 23.61 & 25.5 & 3.28 & 3.43 \\
\hline $\begin{array}{l}\mathrm{T}_{6}: \mathrm{VR}-847 \text { (Sri } \\
\text { chaitanya)(110-115 days) }\end{array}$ & 6.65 & 7.3 & 6.88 & 7.3 & 22.74 & 25.4 & 3.19 & 3.49 \\
\hline $\begin{array}{l}\mathrm{T}_{7}: \text { VR-762(Bharathi)(110- } \\
\text { 115days) }\end{array}$ & 7.22 & 7.6 & 6.99 & 7.3 & 23.46 & 25.3 & 3.61 & 3.57 \\
\hline $\mathrm{T}_{8}: \quad$ VR-900(110-117 days) & 6.69 & 8.2 & 7.21 & 8.0 & 23.22 & 25.3 & 3.35 & 3.78 \\
\hline CD (0.05) & 0.75 & 0.96 & 0.95 & 0.93 & 3.36 & NS & 0.41 & 0.29 \\
\hline $\mathrm{CV} \%$ & 6.55 & 7.65 & 8.29 & 7.71 & 8.32 & 1.71 & 7.72 & 5.05 \\
\hline
\end{tabular}


Table.3 Yield and economics of finger millet varieties under rice fallow conditions

\begin{tabular}{|c|c|c|c|c|c|c|c|c|}
\hline \multirow{2}{*}{ Treatments } & \multicolumn{2}{|c|}{ Grain yield $(\mathrm{kg} / \mathrm{ha})$} & \multicolumn{2}{|c|}{$\begin{array}{l}\text { Straw yield } \\
(\mathrm{kg} / \mathrm{ha})\end{array}$} & \multicolumn{2}{|c|}{ NMR (Rs./ha) } & \multicolumn{2}{|c|}{$\mathrm{B}: \mathrm{C}$ ratio } \\
\hline & $2015-16$ & $\begin{array}{l}2016- \\
17\end{array}$ & $\begin{array}{l}2015- \\
16\end{array}$ & $\begin{array}{l}2016- \\
17\end{array}$ & $\begin{array}{l}2015- \\
16\end{array}$ & $\begin{array}{l}2016- \\
17\end{array}$ & $\begin{array}{l}2015- \\
16\end{array}$ & $\begin{array}{l}2016- \\
17\end{array}$ \\
\hline $\begin{array}{l}\mathrm{T}_{1}: \text { Udaramalligae }(60-65 \\
\text { days) }\end{array}$ & 652.00 & 1516.7 & $\begin{array}{c}2036.3 \\
3\end{array}$ & 4496.7 & 3343 & 18987 & 0.34 & 1.32 \\
\hline $\begin{array}{l}\mathrm{T}_{2}: \text { VR-708(Champavathi) } \\
\text { (80-85 days) }\end{array}$ & 704.67 & 1923.3 & $\begin{array}{c}2380.6 \\
7\end{array}$ & 5505.7 & 4396 & 27433 & 0.45 & 1.84 \\
\hline $\mathrm{T}_{3}:$ Maruthi (85-90 days) & 725.00 & 1820.0 & $\begin{array}{c}2697.6 \\
7\end{array}$ & 5373.3 & 4803 & 25160 & 0.50 & 1.69 \\
\hline $\mathrm{T}_{4}:$ PRS-2 (85-90 days) & 749.67 & 2113.3 & $\begin{array}{c}2518.3 \\
3\end{array}$ & 6184.7 & 5296 & 31613 & 0.55 & 2.12 \\
\hline $\mathrm{T}_{5}:$ Vakula (100-105 days) & 868.67 & 2136.7 & $\begin{array}{c}2825.3 \\
3\end{array}$ & 6234.3 & 7676 & 31627 & 0.79 & 2.06 \\
\hline $\begin{array}{l}\mathrm{T}_{6}: \text { VR-847 (Sri chaitanya) } \\
\text { (110-115 days) }\end{array}$ & 786.33 & 2383.3 & $\begin{array}{c}2688.3 \\
3\end{array}$ & 7012.3 & 6030 & 36553 & 0.62 & 2.30 \\
\hline $\begin{array}{l}\mathrm{T}_{7}: \text { VR-762(Bharathi) } \\
\text { (110-115days) }\end{array}$ & 1023.33 & 2436.7 & $\begin{array}{c}3328.0 \\
0\end{array}$ & 7197.7 & 10770 & 37727 & 1.11 & 2.38 \\
\hline $\begin{array}{l}\mathrm{T}_{8}: \text { VR-900(110-117 } \\
\text { days) }\end{array}$ & 997.67 & 2503.3 & $\begin{array}{c}3306.6 \\
7\end{array}$ & 7387.7 & 10256 & 39193 & 1.06 & 2.47 \\
\hline CD (0.05) & 135.26 & 408.2 & 342.37 & 1243.2 & - & - & - & - \\
\hline CV \% & 9.50 & 11.1 & 7.18 & 11.5 & - & - & - & - \\
\hline
\end{tabular}

Ragi crop is very sensitive to weed growth in the initial stages. Weeds pose one of the major constraints in the worldwide production of finger millet. Owing to initial slow growth of the finger millet favours weed growth, which causes more competition for sunlight, nutrient and water in early stages of growth lead in lowering productivity (Lall and Yadav, 1982). Ramachandra Prasad et al., (1991) reported 55-61\% reduction in grain yield of finger millet due to weed growth. Millets are very susceptible to competition from weeds early in the life of the crop. Therefore efficient weed control at the preand early post emergence stages is essential. Once the crop reaches approximately $0.5 \mathrm{~m}$ in height, weed control no longer affects yield (Mishra, 2015). With the inclusion of one intercultural operation within the critical period of crop weed competition during 2016-
17, helped in reducing the crop weed competition and in turn increasing the grain yield. Among different varieties, grain yield and straw yields were significantly high for VR-762 (Bharathi) (1023.3kg/ha, $3328.0 \mathrm{~kg} / \mathrm{ha}$ respectively) during 2015-16, however, it was on par with VR-900. But, in 2016-17 maximum grain yields were recorded in VR-900 (2503.3kg/ha and $7387.7 \mathrm{~kg} / \mathrm{ha})$, which was statistically on par with VR-762, VR-847, Vakula and PRS-2. Higher yield attributes of these varieties might have contributed to the higher grain yields. Lowest grain and straw yields were recorded in the variety Udaramalligae during both the years owing to its poor growth and yield attributes (Table 3). Considering the economics of both years, remarkable increase in the net monetary returns was seen during 2016-17 compared to the previous year (Table 3). 
Instead of leaving the finger millet crop after sowing, same as the farmers do in the pulses, particularly in the North Coastal Zone, inclusion of crop management practices have led to remarkable increase in the yields and net returns. Net income and Benefit cost ratio were found to be maximum with VR-900 followed by VR-762 and VR-847.

In conclusion, about $30 \%$ (11.7 mha) of the area under rice production during kharif season in India remain fallow in the subsequent rabi due to number of biotic, abiotic and socioeconomic constrains. Hence, there is an enormous scope for finger millet to expand its area, production and productivity. In Rice fallows, use of higher seed rate of finger millet because of uncertainty in crop stand establishment, every so often results in higher plant population per unit area. High plant population will result in heavy competition amongst the plants for moisture, nutrients and solar radiation and finally lead to marked reduction in the yields. Moreover, initial slow growth of the finger millet favours heavy weed infestation and in turn drastic reduction in grain yields. Unlike finger millet, in Rice-pulse system, pulses can manage the weed growth because of their rapid smothering habit. Hence, there is an immense need to incorporate thinning and gap filling and intercultivation with hand weeding operations to enhance the grain yields of Finger millet in Rice fallows. Regarding varieties, long duration varieties (VR-900, VR-762 and VR-847) provided with 2-3 irrigations or medium duration varieties (PRS-2 and Vakula) provided with 1-2 irrigations are beneficial for cultivation under rice fallows in North Coastal Zone of Andhra Pradesh.

\section{References}

Getahun Dereje, Tigist Adisu and Bekele Anbessa. 2016. Influence of row spacing and seed rate on yield and yield components of Finger Millet at Assosa Zone in Benshagul Gumuze region of Ethiopia. J. Biol. Agri. Healthcare, Vol. 6(5): 42-45.

Lall, M. and Yadav, L.N.S. 1982. Critical time of weed removal in finger millet. Indian $J$. Weed Sci., 14: 85-88.

Mishra, J.S. 2015. Weed management in millets: Retrospect and prospects. Indian J. Weed Sci., 47(3): 246-253.

Ramachandra Prasad, R.V., Narasimha, N., Dwarkanath, N., Munigowda, M. K and Krishnamurthy, K. 1991. Integrated weed management in drilled finger millet. Mysore J. Agri. Sci., 25: 13-17.

Rangaswamy, R. 1995. A text book of agricultural statistics. New age International (p) Ltd., Publishers, New Delhi, India, $1^{\text {st }}$ edition paper back pp.1-358.

Singh, R.G., Mishra, S.K., Singh, P.K., Jat, R.K., Dey, S., Shahi, V.B., Lahri, A., Bishwas, B., Sarkar, S., Bhattacharyya, P., Kumar, S. and Gupta, R.K. 2012. Opportunities for managing rice-fallow systems with conservation agriculture technologies. Indian Farming, 62(6): 31-34: 40.

Wade, L.J., Norris, C.P. and Walsh, P.A. 1988. Effects of suboptimal plant density and nonuniformity in plant spacing on grain yield of rain-grown sunflower. Australian $J$. Experimental Agri., 28: 617-622.

\section{How to cite this article:}

Triveni, U., Y. Sandhya Rani, T.S.S.K. Patro, N. Anuradha and Divya, M. 2017. Assessment of Production Potential of Finger Millet (Eleusine coracana (L.) Gaertn.) under Rice-Fallow Conditions of North Coastal Zone of Andhra Pradesh. Int.J.Curr.Microbiol.App.Sci. 6(7): 918923. doi: https://doi.org/10.20546/ijcmas.2017.607.113 